\title{
Albert Einstein
}

Mileva Marić

b'

The Love Letters 



\section{Albert Einstein}

\section{Mileva Marić}

s)

The Love Letters

EDITED AND WITH AN

INTRODUCTION BY

JÜRGEN RENN AND

Robert Schulmann

TRANSLATED BY

SHAWN SMITH

PRINCETON UNIVERSITY PRESS

PRINCETONANDOXFORD 
Copyright (C) 1992 by Princeton University Press

Published by Princeton University Press, 41 William Street,

Princeton, New Jersey 08540

In the United Kingdom: Princeton University Press,

3 Market Place, Woodstock, Oxfordshire OX20 1SY

All Rights Reserved

Second printing, and first paperback printing, 2001

Paperback ISBN 0-691-08886-1

The Library of Congress has cataloged the cloth edition of this book as follows

Einstein, Albert, 1879-1955.

[Correspondence. English. Selections]

Albert Einstein/Mileva Maric - the love letters / with an introduction by Jürgen Renn and Robert Schulmann ; translated from the German by Shawn Smith.

p. $\mathrm{cm}$.

Includes bibliographical references.

ISBN 0-691-08760-1

1. Einstein, Albert, 1879-1955-Correspondence.

2. Einstein-Marić, Mileva, 1875-1948-Correspondence.

3. Physicists-Correspondence. I. Einstein-Marić, Mileva, 1875-1948. II. Renn, Jürgen, 1956- . III. Schulmann,

Robert J., 1942- . IV. Smith, Shawn, 1968- . V. Title.

VI. Title: Love letters.

QC16.E5A4 1992

$530^{\prime \prime} .092-\mathrm{dc} 20 \quad 91-40183$

This book has been composed in Adobe Times Roman

Designed by Jan Lilly

Printed on acid-free paper. $\infty$

www.pup.princeton.edu

Printed in the United States of America

$\begin{array}{lllllllll}10 & 9 & 8 & 7 & 6 & 5 & 4 & 3 & 2\end{array}$ 
The imagination of a boy is healthy, and the mature imagination of a man is healthy; but there is a space of life between, in which the soul is in a ferment, the character undecided, the way of life uncertain, the ambition thick-sighted: thence proceeds mawkishness, and all the thousand bitters which those men I speak of must necessarily taste in going over the following pages.

John Keats, Preface to Endymion (1818) 
